\title{
Induction apoptosis and G2/M phase cell cycle arrest by non-ther- mal plasma in human osteosarcoma MG-63 cell line
}

\author{
Byul Bo Ra Choi and Gyoo Cheon Kim* \\ Department of Oral Anatomy, School of Dentistry, Pusan National University, Yangsan 50612, Republic of Korea \\ (Received Sep 5, 2017; Revised version received Sep 19, 2017; Accepted Oct 11, 2017)
}

\begin{abstract}
Osteosarcoma is a malignant bone tumor that develops in the osteoblast cells that form the outer covering of bone. It is the most frequent malignant bone tumor found at 10-14 years and at $>65$ years of age. Atmospheric pressure plasma has advantages of high density and rich chemical agents without elevation of the substrate temperature. These non-equilibrium characteristics show promising applications in the biomedical field, opening a new research area called "Plasma Medicine", which includes sterilization, coagulation, wound healing, and cancer treatment. However, the mechanism of apoptosis caused by plasma treatment in osteosarcoma is not well understood. In this study, the researchers show that microwave plasma causes selective cell cycle arrest and apoptosis in osteosarcoma cells in vitro. An inhabitation of cell growth of microwave plasma showed that this plasma has selective cytotoxic effects on MG-63 cells in comparison to hFOB 1.19 cells. Also, the resesearchers observed that microwave plasma treatmenst significantly showed disruption and aggregation of F-actin. The results demonstrated that treatment of MG-63 cells with microwave plasma induced cell cycle arrest in the G2/M phase, using flow cytometry and western blot assay. To detect PARP and DFF-45 cleavage or a decrease as a result of caspase-3 activation, MG63 cells were treated either with various times of microwave plasma. The research studies demonstrated that microwave plasma induced G2/M cell phase arrest and triggered apoptosis.
\end{abstract}

KEY WORDS: Apoptosis, Cell cycle arrest, Non-thermal plasma, Osteosarcoma

\section{서 론}

골육종은 뼈에 발생하는 흔한 원발성 악성종양으로, 악 성도가 높은 경우에는 전이의 위험이 크다 $[1,2]$. 또한 10 대 와 20대에서 가장 흔히 발생되며 남성이 여성보다 발생율이 더 높은 편이다 $[3,4]$. 과거 항암 약물 치료 없이 수술적 치 료만 시행한 경우에는 골육종 환자의 5 년 생존율이 $20 \%$ 미 만[1,2]으로 매우 낮기 때문에 골육종의 성장을 억제하거나 세포사멸을 일으킬 수 있는 다른 방법이 필요한 실정이다.

플라즈마는 고체, 액체, 기체 단계를 지난 제4의 물질상 태로서 최근 다양한 분야에 많이 응용되고 있다 $[5,6]$. 현재 소독, 혈액 응고, 피부 재생, 암 치료 등 의학적 응용[7]이 가능하며 레이저와 달리 열 적인 손상이 적다는 것이 장점 이다. 최근 연구에서 몇몇의 잘 알려진 암세포의 죽음과 성

*Corresponding author: Gyoo-Cheon Kim

Department of Anatomy and Cell Biology, School of Dentistry, Yangsan Campus of Pusan National University, 49 Busandaehak-ro, Mulgeumeup, Yangsan-si, Gyeongsangnam-do 50612, Republic of Korea

Tel.: +82-510-8243, Fax: +82-51-510-8241

E-mail:ki91000m@pusan.ac.kr
장 저해, 즉 세포자멸사를 유도하는 것으로 많은 발표가 되 고 있다[8,9]. 세포 주기 정지와 세포자멸사는 암세포의 성 장저해 및 죽음을 유도하는 한 방법으로 앞서 설명된 암 치 료에 있어 매우 중요하다고 볼 수 있다.

세포는 $\mathrm{G} 1, \mathrm{~S}, \mathrm{G} 2$ 그리고 $\mathrm{M}$ 기의 순으로 계속 순환되는 데 이 중 $\mathrm{S}$ 기는 $\mathrm{DNA}$ 의 복제가 일어나고 $\mathrm{M}$ 기는 세포분열 이 일어난다. 이 사이의 휴지기를 G1기과 G2기라고 하는 데 이 시기는 분열과 복제가 완전히 일어났는지 확인하는 단계이다. 세포 주기를 진행하는 데에 있어 핵심적으로 세 포주기를 진행시키는 cyclin-dependent kinases (CDK)와 cyclin간의 특이적인 조절이 이루어진다. G1기에는 cyclin $\mathrm{D} / \mathrm{CDK} 4, \mathrm{~S}$ 기에는 cyclin $\mathrm{A} / \mathrm{CDK} 2$, 그리고 $\mathrm{G} 2 / \mathrm{M}$ 기에는 cyclin $\mathrm{B} / \mathrm{CDC} 2$ 복합체가 각각 세포주기조절에 관여한다. 만 약 세포의 손상이 일어날 시 세포 주기는 정지된다[10-12].

세포자멸사는 세포 골격 붕괴, 세포막 변화 및 DNA 절 편화의 특징을 가지며 외인성 경로와 내인성 경로로 구별 되는데 특히 내인성 경로는 미토콘드리아의 기능이상으로 발생된다. 이 경로는 미토콘드리아의 막전위 변화로 AIF (apoptosis inducing factor)가 핵이나 세포질로 방출된다거 나 caspase cascade를 유발하여 caspase 3 의 최종 활성화를 
통해 세포자멸사가 일어난다. Caspase는 protease의 한 일 종이며, 세포자멸사가 유도되면 세포 내 손상된 세포를 인 식하고 보호하는 일에 관여하는 poly ADP-ribose polymerase (PARP)나 caspase의 활성화를 억제시키는 Inhibitor caspase activated DNase (ICAD)와 같은 단백질을 분해하는 역할 을 한다[13-15].

현재 플라즈마에 의한 골육종 세포의 증식 억제 및 세 포자멸사에 관련한 기전 연구는 매우 부족한 실정이다. 이 에 본 연구에서는 플라즈마에 의한 골육종 세포의 증식에 미치는 영향을 관찰하고 세포자멸사 효과에 대한 기전을 규명하고자 하였다.

\section{재료 및 방법}

\section{항체}

Rabbit polyclonal anti-human cyclin B1, DFF (DNA fragmentation factor)-45 항체들은 Santa Cruz Biotechnology (Santa Cruz, CA, USA)에서 구입하였고 mouse monoclonal anti-human CDC2, PARP-1, caspase 3, GAPDH (Glyceraldehyde 3-phosphate dehydrogenase) 항체들은 Santa Cruz Biotechnology (Santa Cruz, CA, USA)로부터 구입하여 1:3000으로 희석하여 실험에 사용하였다.

\section{세포주 및 셰포배양}

본 실험에 사용된 세포는 골육종세포인 MG-63과 골모세 포인 $\mathrm{hFOB} 1.19$ 를 사용하였다. 각각의 세포는 American Type Culture Collection (Rockville, MD, USA)에서 분양 을 받아서 본 실험에 사용하였다. MG-63세포는 $25 \mathrm{mM}$ Hepes, $100 \mu \mathrm{g} / \mathrm{ml}$ penicillin/streptomycin, $4 \mathrm{mM}$ L-glutamine, $10 \%$ fetal bovine serum가 함유된 Dulbecco's modified Eagle's medium 배지를 사용하였고 $37^{\circ} \mathrm{C}, 5 \% \mathrm{CO}_{2}$ 배양기 에 배양되었다. hFOB 1.19세포는 $25 \mathrm{mM}$ Hepes, $100 \mu \mathrm{g} /$ $\mathrm{ml}$ penicillin/streptomycin, $4 \mathrm{mM}$ L-glutamine, $10 \%$ fetal bovine serum가 함유된 Dulbecco's Modified Eagle Medium: Nutrient Mixture F-12 (DMEM/F12) 1:1 배지를 사용하였 고 $34^{\circ} \mathrm{C}, 5 \% \mathrm{CO}_{2}$ 배양기에 배양되었다.

\section{저온 상압 플라즈마}

실험에 사용된 플라즈마는 Fig. 1과 같다. 플라즈마는 전 력 공급 장비를 이용하게 설계되었으며 $900-\mathrm{MHz}$ 의 주파 수로 가해진다. 또한 아르곤 가스는 $2.5 \mathrm{slm}$ 으로 관을 통 과하도록 하였다. 플라즈마를 처리하기 위해 크기 $35 \varnothing$ 의 $\mathrm{dish}$ 를 사용했으며, 처리하기 24시간 전 세포를 분주하여 배양하였다. 배양기에 24시간 동안 배양 후 $2 \mathrm{ml}$ 의 새 배 지로 교환하여 $1 \mathrm{~cm}$ 거리를 두고 플라즈마를 처리하였다. 플

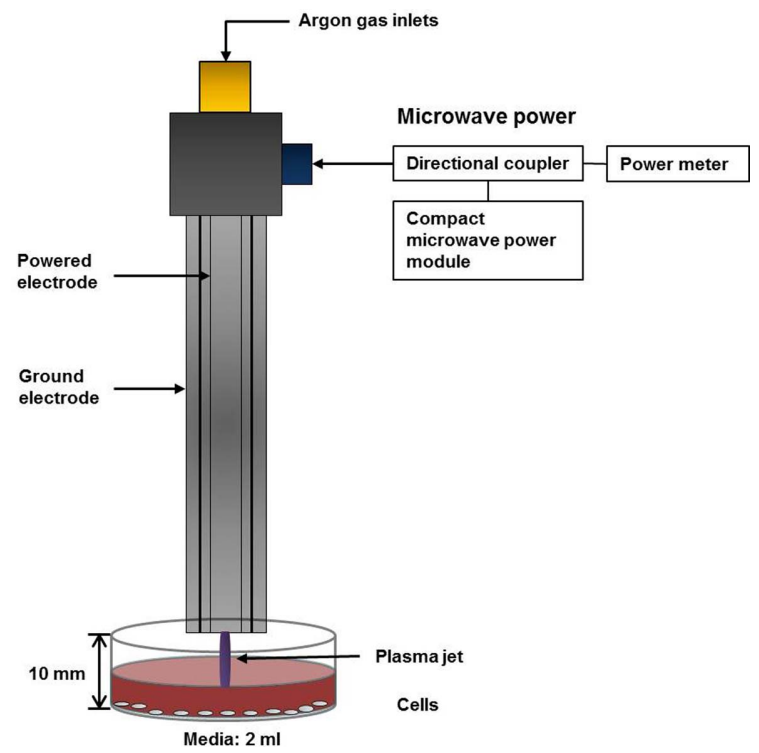

Fig. 1. Schematic diagram of plasma device and process.

라즈마의 처리 시간은 1 분, 3 분, 5 분으로 처리하였으며 처 리된 세포는 다시 배양기에 24시간 배양하였다.

\section{Cell viability assay}

플라즈마를 처리한 후 세포 생존율을 확인하게 위해 WST-1 분석을 하였다. $35 \varnothing$ dish에 $2 \times 10^{5}$ 개의 세포를 분 주한 후 24 시간 동안 배양하였다. 24시간 뒤 세포의 상층 액을 제거하고, 새로운 배지로 바꾼 다음, 플라즈마를 1 분, 3 분, 5 분씩 처리하였다. 그런 다음 24 시간 이후 배지를 제 거하고 phosphate buffered saline (PBS)로 세척하였다. 200 $\mu \mathrm{l}$ 의 WST-1 용액을 배지와 희석한 다음 각 dish에 넣고 2 시간 동안 처리하였다. 이후, ELISA reader (Sunrise Remote Control, Tecan, Austria)로 $450 \mathrm{~nm}$ 파장에서 흡광도를 측 정한 다음 그래프로 백분율로 환산하여 나타내었다. 이 분 석은 3회 정도 반복하여 시행하였다.

\section{F-actin stain}

플라즈마가 세포 내의 골격 배열에 미치는 영향을 확인 하기 위해 F-actin염색 후 관찰을 하였다. Cover slip에 $50 \mu \mathrm{g} /$ $\mathrm{ml}$ 농도의 콜라겐으로 24시간 코팅시킨 후 DPBS (Dulbecco's phosphate-buffered saline)로 세척하였다. 그런 다음 Cover slip에 세포를 $3 \times 10^{4}$ 으로 분주한 뒤 24시간 동안 배양하였 다. 24시간 이후 플라즈마를 처리하기 위해 $35 \varnothing \mathrm{dish}$ 에 세포가 부착된 cover slip을 넣은 다음 플라즈마를 5 분 동 안 처리하였다. 처리한 세포는 다시 24시간을 배양한 후 DPBS로 세척하였다. 그 후 고정액인 4\% Paraformaldehyde 용액을 처리하고 PBS 로 세척 후 $0.1 \%$ Triton X-100을 이 용하여 10 분간 세포막을 투과시켰다. 염색약인 Rhodamine phalloidin을 $1 \% \mathrm{BSA}$ 에 희석한 다음 30 분간 $37^{\circ} \mathrm{C}$ 의 암실 
에서 반응시켰다. PBS로 3번 세척 후 DAPI (4',6-diamidino-2phenylindole)가 포함된 용액(Molecular Probes, CA, USA)으 로 봉입한 다음 공초점 레이저 현미경 LSM 700 (Carl Zeiss, Germany)을 이용하여 관찰하였다.

\section{Flow cytometry assay}

$35 \varnothing$ dish에 $2 \times 10^{5}$ 개의 세포를 분주한 후 24 시간 동안 배양하였다. 24 시간 뒤 세포의 상층액을 제거하고, 새로운 배지로 바꾼 다음, 플라즈마를 1 분, 3 분, 5 분씩 처리하였다. 그런 다음 24시간 이후 세포를 모아 PBS로 세척하였다. 각각의 세포들을 $70 \%$ 에탄올에 고정한 다음 $4^{\circ} \mathrm{C}$ 에 24 시 간 보관하였다. 24시간 후 $\mathrm{PBS}$ 로 세척을 하고 RNase A를 $100 \mu \mathrm{g} / \mathrm{ml}$ 이 되도록 넣어준 뒤 PI (Propidium iodide; Sigma, St. Louis, MO, USA)를 $100 \mu \mathrm{g} / \mathrm{ml}$ 의 농도로 처리하였다. 30 분 후 염색된 세포는 수거하여 분석기용 tube에 담아 유 세포 분석기(CYTOMICS FC500 Beckman Coulter, FL, $\mathrm{CA}, \mathrm{USA}$ )를 통해 FL 3파장에서 관찰하였다.

\section{Western blot assay}

$35 ø$ dish에 $2 \times 10^{5}$ 개의 세포를 분주한 후 24 시간 동안 배양 하였다. 24 시간 뒤 세포의 상층액을 제거하고, 새로운 배지로
바꾼 다음, 플라즈마를 1 분, 3 분, 5 분씩 처리하였다. 24 시 간 동안 배양을 하고 이후 세포를 $4^{\circ} \mathrm{C}$ 에서 모은 다음 $\mathrm{PBS}$ 로 세척하였다. 세척한 세포들은 적당량의 lysis buffer (10 $\mathrm{mM}$ Tris/HCl, $\mathrm{pH} 7.2,1 \%$ Triton X-100, $150 \mathrm{nM} \mathrm{NaCl}, 5$ $\mathrm{mM}$ EDTA, protease inhibitor cocktail)를 첨가해 $4^{\circ} \mathrm{C}$ 에서 1 시간 동안 반응시킨 후, 원심 분리를 하고 상층액에 있는 단백질만을 따로 분리했다. 각 단백질의 농도는 Bradford assay를 통해 정량하였다. 동량의 sample을 만든 후 7.5$15 \%$ polyacrylamide SDS gel을 이용해 전기영동으로 분리 하고 PVDF membrane으로 전이시켰다. 전이시킨 PVDF membrane은 각각 1차, 2차 항체를 처리하고 특정 단백질 의 발현 양을 Alpha Imager HP (AlphaInnotech, Santa Clara, CA, USA)를 통해 분석하였다.

\section{통계 분석}

통계 분석을 위해 통계 프로그램인 SPSS Window ver. 12.0 (SPSS Inc., Chicago, IL, USA)을 통해 분석 하였다. 플라즈마를 처리하지 않은 군과 처리한 군을 paired t-test method로 확인하였으며 $\mathrm{p}<0.05$ 으로 분석 한 결과값을 통계학적으로 유의한 차이가 있는 것으로 판단하였다.

A.

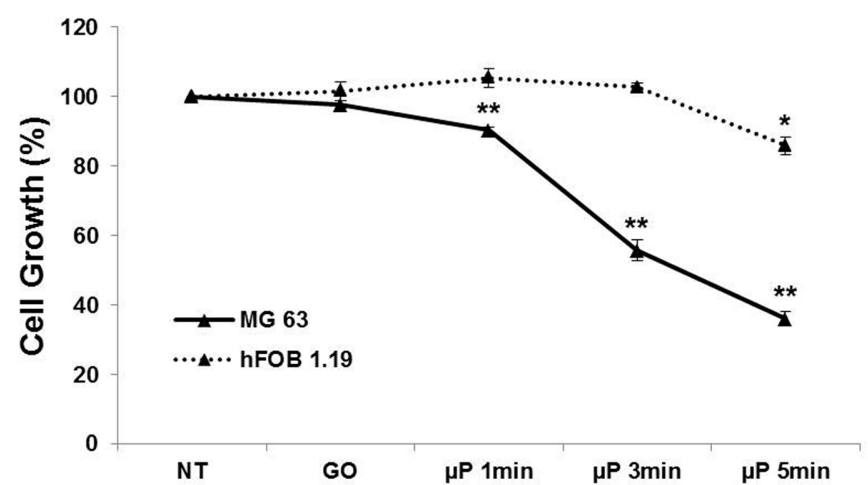

B.

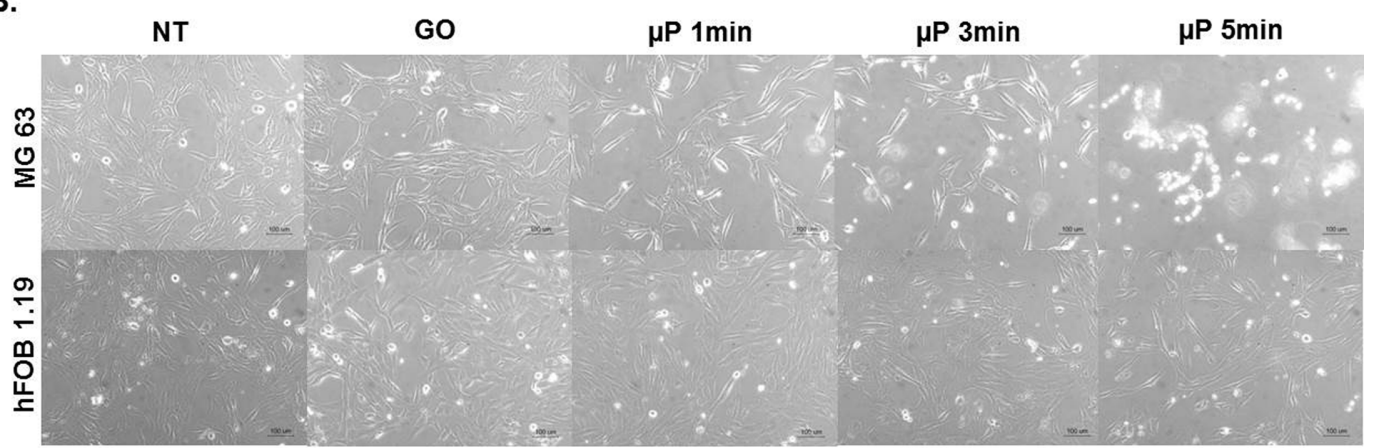

Fig. 2. Cytotoxic effect of plasma on MG-63 and hFOB 1.19 cells. MG-63 and hFOB 1.19 cells were treated with plasma at different times (0-5 min) for $24 \mathrm{~h}$. NT: non treated group, GO: gas treated group, $\mu$ p: plasma treated group.

(A) Cell viability was estimated by WST- 1 assay. ${ }^{*} \mathrm{p}<0.05$ and ${ }^{* *} \mathrm{p}<0.01$ versus control.

(B) Cell morphology was visualized by an inverted light microscopy. 


\section{결 과}

\section{저온 상압 플라즈마에 의한 골육 종세포의 생존율 저해}

플라즈마가 골육종인 $\mathrm{MG}-63$ 세포와 골모세포인 $\mathrm{hFOB}$ 1.19 의 세포 사멸에 미치는 영향을 관찰하기 위해 플라즈마 를 적정시간 처리 후 WST-1 분석을 수행하였다. Fig. $2 \mathrm{~A}$ 의 결과와 같이 플라즈마를 MG-63에 처리 시 $100,98,90,56$, $36 \%$ 으로 처리 시간의 증가에 따라 유의적으로 감소되었다. 반면 플라즈마를 hFOB 1.19에 처리 시 $100,102,105,103$, $86 \%$ 으로 MG-63에 비해 세포사멸효과가 나타나지 않았음을 확인하였다. 또한 Fig. $2 \mathrm{~B}$ 와 같이 현미경 상으로 세포의 형태 학적 모양을 관찰할 시 $\mathrm{hFOB} \mathrm{1.19보다} \mathrm{MG-63에서} \mathrm{세포의}$ 불규칙한 형태와 세포 수의 감소를 확인하였다.

\section{저온 상압 플라즈미에 의한 골육종 세포의 F-actin 형태 이상}

세포 형태를 유지하는 골격을 염색하기 위해 F-actin에 특 이적으로 결합할 수 있는 phalloidin 염색을 시행하였다. 플라 즈마를 처리하지 않은 군에서는 세포 골격이 정상적으로 섬 유형태를 유지하고 있는 것을 관찰하였으나 반면 플라즈마 를 5 분 동안 처리한 군에서는 섬유 다발의 구조가 분리되어 섬유형태의 구조물이 거의 없음을 관찰하였다(Fig. 3).

\section{저온 상압 플라즈마에 의한 골육종 세포의 세포 주기 정지}

플라즈마가 골육종 세포 주기와 관련하여 미치는 영향 을 확인하기 위해 유세포분석을 통해 세포 주기를 분석하

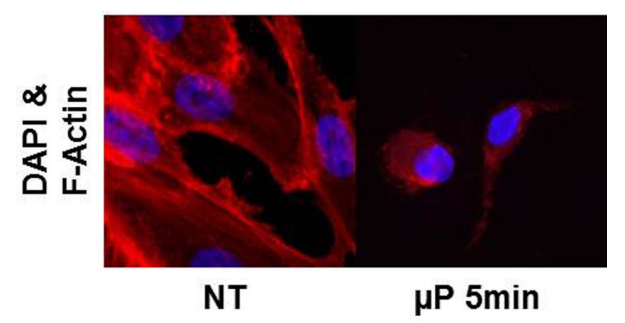

Fig. 3. Morphology of MG-63 cells treated with plasma. The morphology of MG-63 cells was visualized by using F-actin staining after treatment with $5 \mathrm{~min}$ of plasma for $24 \mathrm{~h}$.

였다. 플라즈마를 $1,3,5$ 분으로 처리한 결과, Fig. $4 \mathrm{~A}$ 에 따 르면 플라즈마를 1분 처리 후 $\mathrm{G} 1, \mathrm{~S}, \mathrm{G} 2 / \mathrm{M}$ 기의 세포의 분 포는 $51.5,7.5,29.1 \%$ 이었고, 3 분 처리 후는 $17.9,8.9$, $62.8 \%$ 이었으며, 5 분 처리 후는 $8.4,9,64.1 \%$ 이었다. 이 결과는 $\mathrm{G} 1$ 기의 세포수를 감소시키고 $\mathrm{G} 2 / \mathrm{M}$ 기의 세포수를 증가시켰는데 즉, 플라즈마가 골육종 세포를 $\mathrm{G} 2 / \mathrm{M}$ 기에서 정지시킨다는 것을 의미한다. 또한 세포자멸사를 나타내 는 지표인 sub-G1의 백분율을 관찰했을 시 처리하는 시간 이 증가함에 따라 $2.4 \%, 6.7 \%, 9.9 \%$ 로 증가하였다. 이와 같은 결과로 세포 주기와 관련된 신호 단백질을 관찰하였 을 때 $\mathrm{G} 2 / \mathrm{M}$ 기와 관련된 cyclin $\mathrm{B}$ 와 $\mathrm{CDC} 2$ 가 플라즈마를 각각 3 분과 5 분을 처리하였을 때 다른 군보다 확연히 증 가됨을 확인하였다(Fig. 4B).

\section{저온 상압 플라즈마에 의한 골육종 세포의 세포자멸사 유도}

세포자멸사 신호전달에서의 대표적 최종 산물인 caspase-3와 이의 기질로 알려진 PARP-1과 ICAD의 결과
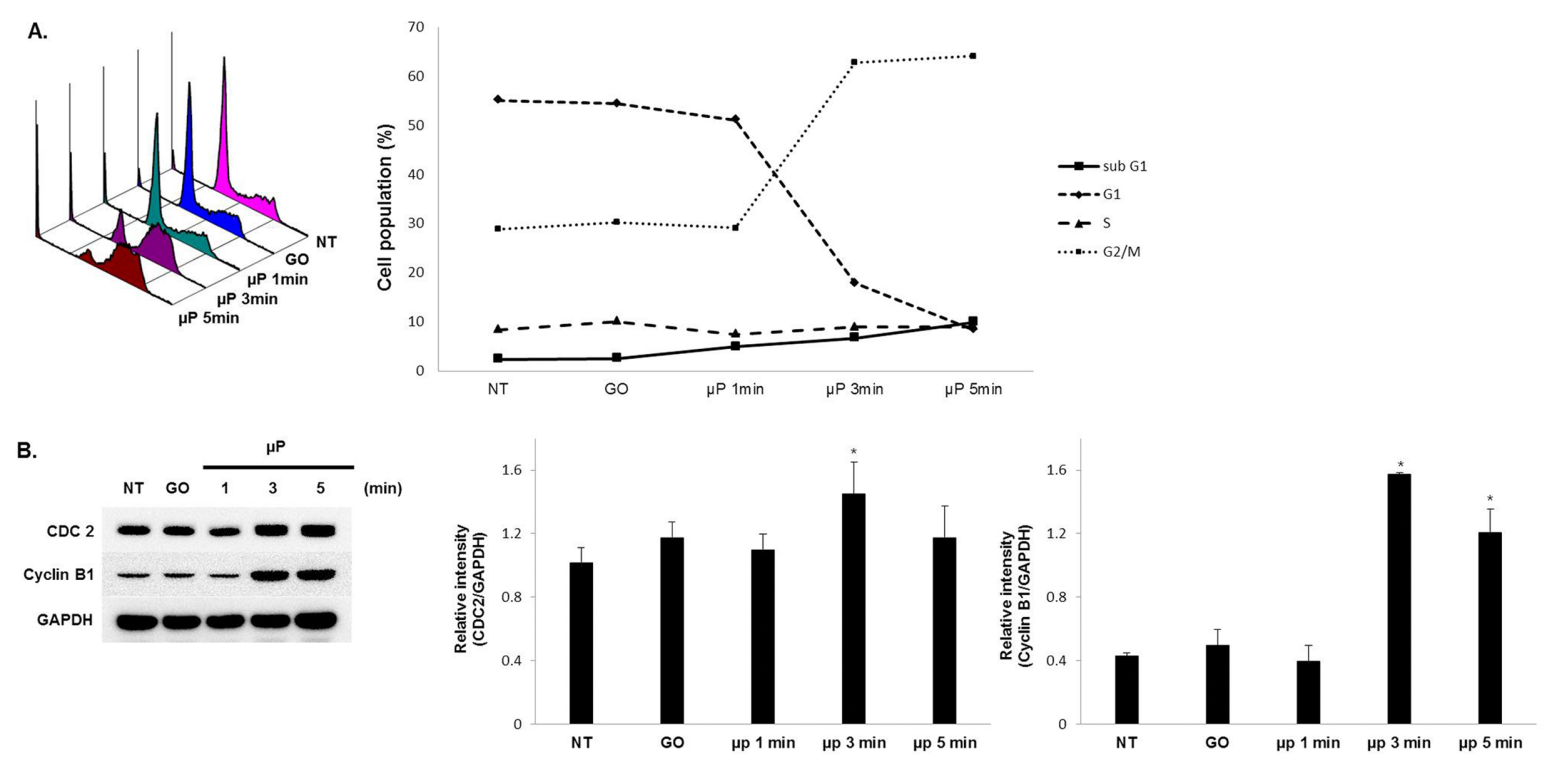

Fig. 4. Cell cycle arrest of MG-63 cells treated with plasma. MG-63 cells were treated with 1-5 min of plasma for $24 \mathrm{~h}$.

(A) The cells were stained with propidium iodide solution and analyzed by using flow cytometry.

(B) The total protein lysates were used for SDS-PAGE followed by western blot analysis. Antibodies against cyclin B1 and CDC 2 were used. ${ }^{*} \mathrm{p}<0.05$ versus control. 

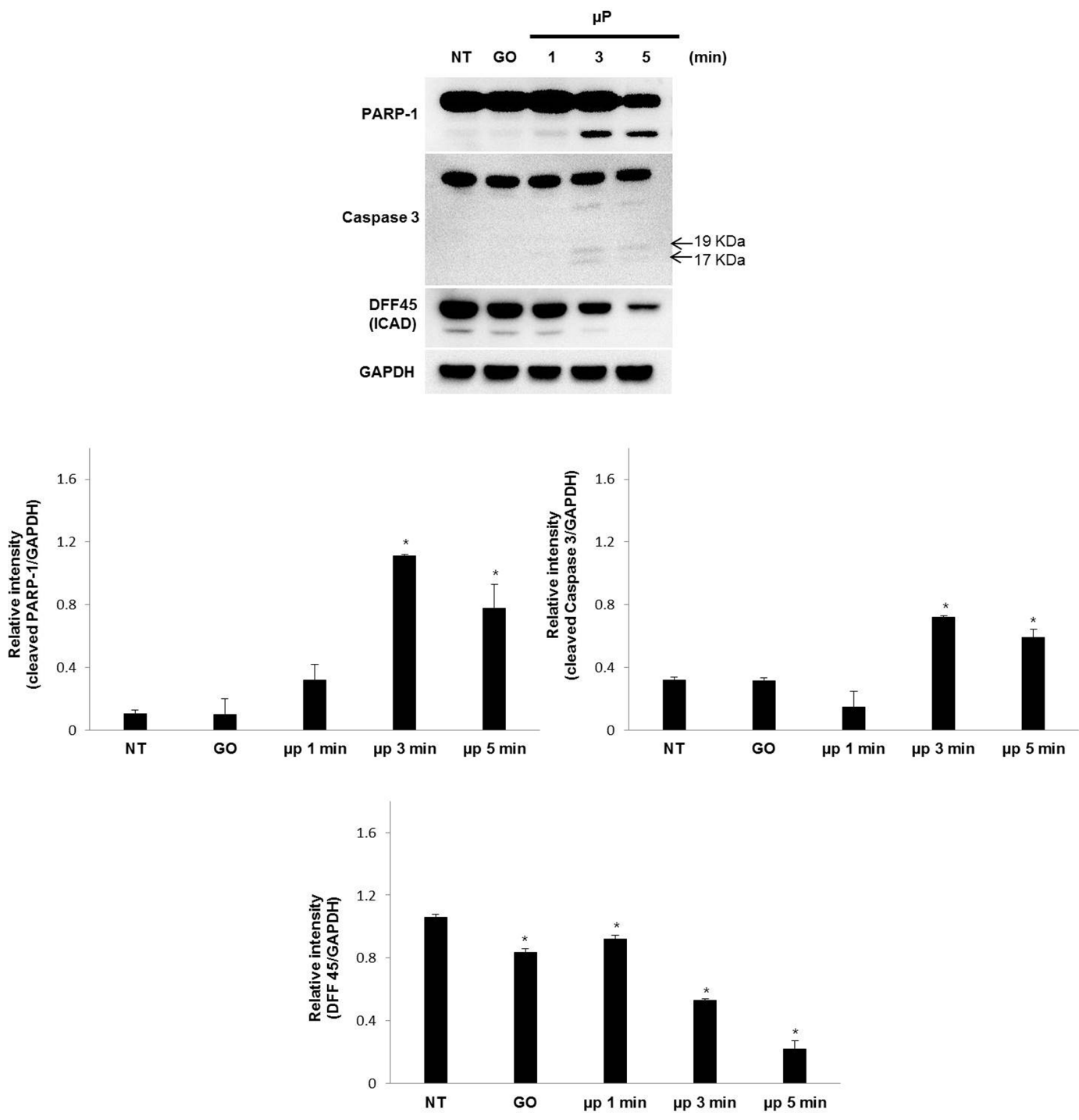

Fig. 5. Expression of apoptosis related protein by plasma treatment in MG-63 cells.

The total protein lysates were used for SDS-PAGE followed by western blot analysis. Antibodies against PARP-1, caspase-3, and DFF 45 were used. ${ }^{*} \mathrm{p}<0.05$ versus control.

를 확인하였다. 실험 결과, 플라즈마를 각각 3 분과 5 분 처 리 시 PARP-1의 $116 \mathrm{kDa}$ 이 줄어드는 반면 $85 \mathrm{kDa}$ 은 증 가된 양상을 보였고 $\mathrm{ICAD}$ 는 $45 \mathrm{kDa}$ 과 $40 \mathrm{kDa}$ 에서 점차 줄어드는 양상을 보였다. 또한 caspase 3의 cleaved form이 라 불리는 $19 \mathrm{kDa}$ 와 $17 \mathrm{kDa}$ 가 3 분 처리 시 증가되는 양 상을 보아 각각의 기질들이 쪼개짐으로써 세포자멸사가 유도되었음을 관찰할 수 있었다(Fig. 5).

\section{고 찰}

플라즈마는 최근 의학 분야에서 각종 질환의 치료 효과 가 뛰어나다고 알려져 있으며 특히 간세포암, 흑색종, 직 장암 그리고 구강편평세포암에서 플라즈마로 인한 세포자
멸사 및 세포 주기 정지로 세포 죽음을 유도한다는 연구 결과가 보고된 바 있다[16-19]. 구강편평세포암에서 많이 발현되는 EGFR의 발현을 감소시킴으로써 선택적 죽음 유 도한다는 보고[20]가 있었으며 흑색종세포에서 TNF$\mathrm{ASK} 1$ 의 기전을 통한 ROS의 발생으로 세포자멸사를 유도 한다는 보고도 있었다[21]. 그 외에도 플라즈마가 화학요 법에 내성이 있는 난소암에서 항종양효과가 있다는 사실 을 in vivo의 실험을 통하여 증명되었다[22].

본 연구에서는 골육종세포로 알려진 MG-63세포에서 플 라즈마가 미치는 영향을 알아보고 이와 관련하여 세포자 멸사와 세포주기정지 여부에 대해 조사하였다.

플라즈마가 골육종 세포의 사멸 효과를 알아보기 위해 WST-1의 분석을 한 결과 플라즈마를 처리 시 처리 시간 의존적으로 감소하였으며 반면 정상세포인 $\mathrm{hFOB} 1.19$ 세 
포에서는 별다른 영향이 없다는 사실을 관찰할 수 있었다. 이 결과, 플라즈마가 골육종 세포인 MG-63에서 시간 의 존적으로 세포 생존율 감소 및 사멸율을 증가시킨다는 것 을 확인할 수 있었다.

액틴은 세포질 내 소기관으로 세포의 형태를 유지하며 섬유 형태로 다발을 이루고 있다. 세포 골격을 이루는 액 틴은 세포 손상 시 무너지게 되면 세포 모양을 유지 하지 못하고 결국에는 세포 사멸이 나타날 수 있다[23]. 본 연 구에서 플라즈마를 처리하지 않을 시 정상적인 액틴을 유 지되는 반면 플라즈마를 5 분 처리 시 액틴의 변화가 일어 나 세포 본래의 형태를 유지하지 못하는 것으로 관찰되었 다. 이는 골육종세포가 플라즈마에 의해 세포 사멸이 유도 된다는 사실을 관찰할 수 있었다.

이러한 세포 생존율 감소 및 세포 골격의 변화를 보이 는 것이 어떠한 기전을 통하여 유발되었는지 확인하기 위 해 유세포 분석과 단백질 발현 변화에 대한 실험을 진행 하였다.

플라즈마를 처리 후 세포 정지가 유도된 사실을 확인하 기 위해 정량적으로 분석이 가능한 유세포 분석기를 사용 하였다. 세포 정지에 대한 분석을 통해 측정한 결과, G2/ $\mathrm{M}$ 기에서 다른 주기에서의 수치보다 증가되는 것으로 확 인되었다. 이는 단백질 발현 실험을 통한 결과와도 유사하 게 나타난다. $\mathrm{G} 2 / \mathrm{M}$ 기에 관련된 cyclin $\mathrm{B} / \mathrm{CDC} 2$ 복합체의 발현이 플라즈마가 3 분 처리 시 증가되는 것을 확인하였 으며 이는 플라즈마가 골육종세포에서 $\mathrm{G} 2 / \mathrm{M}$ 기의 세포 정 지를 유도한다는 사실을 나타난다.

PARP-1은 DNA의 복구를 위해 세포 내에서 매우 중요 한 역할을 하는데 세포자멸사 과정에서 caspase-3가 활성 이 되면 PARP-1의 절단 현상이 일어나고 손상된 세포를 복구하는 능력을 소실하게 된다[24, 25]. 그 중 capase-3의 표적 기질 중 하나인 DFF 45 도 마찬가지로 세포자멸사가 유발되면 세포 내에서 분해가 일어나 단편화 현상이 일어 나게 되며 미토콘드리아에 위치하고 있는 AIF도 핵이나 세포질 내로 이동하게 된다[26].

Western blot분석법을 시행한 결과 PARP-1에서 플라즈 마를 3 분 처리 시 기질이 단편화되기 시작하면서 5 분 처 리 시에는 기질 자체에서도 감소가 되어 있는 현상을 확 인하였다. 또한 caspase 3 도 마찬가지로 3 분 처리 시부터 활성화 및 단편화가 시작되는 것을 확인하였고 DFF 45 는 플라즈마의 처리 시간이 증가함에 따라 기질이 점차 감소 되는 현상을 관찰하였다. 이는 플라즈마를 골육종세포에 처리 시 세포자멸사와 관련된 기질들이 분절이 되면서 세 포자멸사를 유도했다고 볼 수 있다.

본 연구는 플라즈마가 정상세포인 $\mathrm{hFOB} 1.19$ 세포에서 세포 사멸의 효과를 보이지 않는 반면 MG-63세포에서 특 이적 세포 사멸의 효과를 나타나는 것으로 확인되었다. 이
는 정상세포와 암세포 사이의 함유된 활성 산소 차이인 것 으로 생각된다. 암세포가 정상세포보다 활성산소의 비율 이 높기 때문에 플라즈마를 처리 시 정상세포보다 더 빠 른 세포 사멸의 효과를 나타나게 된다[27]. 이를 바탕으로 실험한 결과 암 세포의 세포 주기 억제 효과를 확인하였 으며 이는 세포자멸사로 인한 세포 사멸까지 유도한다는 사실을 확인할 수 있었다. 이는 추후 플라즈마가 암 치료 장치로서의 가능성을 보이며 보다 암 치료에 있어 중요한 역할을 할 수 있을 것으로 생각된다.

비록 본 연구에서는 정상세포인 $\mathrm{hFOB} 1.19$ 세포에서의 세포골격, 세포주기, 세포 사멸 반응에 대해 연구하지 않 았으나 후속 연구를 통해 보다 많은 연구가 이루어져야 할 것으로 사료된다.

\section{감사의 글}

이 논문은 부산대학교 기본연구지원사업(2년)에 의하여 연구되었음(Kim GC).

\section{Conflict of Interest}

The authors declare that they have no competing interests.

\section{ORCID}

$\begin{array}{ll}\text { Byul Bo Ra Choi } & 0000-0001-7134-9734 \\ \text { Gyoo Cheon Kim } & 0000-0003-3568-3529\end{array}$

\section{References}

1. Ritter J, Bielack SS. Osteosarcoma. Ann Oncol 2010;21: vii320-325. doi: 10.1093/annonc/mdq276.

2. Eilber F, Giuliano A, Eckardt J, Patterson K, Moseley S, Goodnight J. Adjuvant chemotherapy for osteosarcoma: a randomized prospective trial. J Clin Oncol 1987;5:2126. doi: 10.1200/JCO.1987.5.1.21.

3. Hogendoorn PC; ESMO/EUROBONET Working Group, Athanasou N, Bielack S, De Alava E, Dei Tos AP, et al. Bone sarcomas: ESMO clinical practice guidelines for diagnosis, treatment and follow-up. Ann Oncol 2010;21: v204-213. doi: 10.1093/annonc/mdq223.

4. Morishita M, Kawamoto T, Hara H, Onishi Y, Ueha T, Minoda M, Katayama E, Takemori T, Fukase N, Kurosaka M, Kuroda R, Akisue T. AICAR induces mitochon- 
drial apoptosis in human osteosarcoma cells through an AMPK-dependent pathway. Int J Oncol 2017;50:23-30. doi: 10.3892/ijo.2016.3775.

5. Suzuki K, Yoshino D. Proliferation-related activity in endothelial cells is enhanced by micropower plasma. Biomed Res Int 2016;2016:4651265. doi: 10.1155/2016/ 4651265.

6. Liu Y, Liu Q, Yu QS, Wang Y. Nonthermal atmospheric plasmas in dental restoration. Dent Res 2016;95:496505. doi: 10.1177/0022034516629425.

7. Karki SB, Yildirim-Ayan E, Eisenmann KM, Ayan H. Miniature dielectric barrier discharge nonthermal plasma induces apoptosis in lung cancer cells and inhibits cell migration. Biomed Res Int 2017;2017:8058307. doi: $10.1155 / 2017 / 8058307$.

8. Lee SY, Kang SU, Kim KI, Kang S, Shin YS, Chang JW, Yang SS, Lee K, Lee JS, Moon E, Kim CH. Nonthermal plasma induces apoptosis in ATC cells: involvement of JNK and p38 MAPK-dependent ROS. Yonsei Med J 2014;55:1640-1647. doi: 10.3349/ymj.2014.55.6.1640.

9. Ma Y, Ha CS, Hwang SW, Lee HJ, Kim GC, Lee KW, Song K. Non-thermal atmospheric pressure plasma preferentially induces apoptosis in p53-mutated cancer cells by activating ROS stress-response pathways. PLoS One 2014;9:e91947. doi: 10.1371/journal.pone.0091947.

10. Karimian A, Ahmadi Y, Yousefi B. Multiple functions of p21 in cell cycle, apoptosis and transcriptional regulation after DNA damage. DNA Repair (Amst) 2016;42:63-71. doi: 10.1016/j.dnarep.2016.04.008.

11. Wang X, Simpson ER, Brown KA. p53: protection against tumor growth beyond effects on cell cycle and apoptosis. Cancer Res 2015;75:5001-5007. doi: 10.1158/00085472.CAN-15-0563.

12. Kondo S. Apoptosis by antitumor agents and other factors in relation to cell cycle checkpoints. J Radiat Res 1995;36:56-62. doi: 10.1269/jrr.36.56.

13. Hickman JA. Apoptosis induced by anticancer drugs. Cancer Metastasis Rev 1992;11:121-139.

14. Boland K, Flanagan L, Prehn JH. Paracrine control of tissue regeneration and cell proliferation by Caspase- 3 . Cell Death Dis 2013;4:e725. doi: 10.1038/cddis.2013.250.

15. Akao Y, Yamada H, Nakagawa Y. Arsenic-induced apoptosis in malignant cells in vitro. Leuk Lymphoma 2000; 37:53-63.

16. Yan X, Z Xiong, F Zou, S Zhao, X Lu, G Yang, G He, K Ostrikov. Plasma-induced death of HepG2 cancer cells: intracellular effects of reactive species. Plasma Proc Polymers 2012;9:59-66. doi: 10.1002/ppap.201100031.

17. Sensenig R, Kalghatgi S, Cerchar E, Fridman G, Shereshevsky A, Torabi B, Arjunan KP, Podolsky E, Fridman A, Friedman G, Azizkhan-Clifford J, Brooks AD. Nonthermal plasma induces apoptosis in melanoma cells via pro- duction of intracellular reactive oxygen species. Ann Biomed Eng 2011;39:674-687. doi: 10.1007/s10439-010-0197-x.

18. Kim CH, S Kwon, JH Bahn, K Lee, SI Jun, PD Rack, Baek SJ. Effects of atmospheric nonthermal plasma on invasion of colorectal cancer cells. Appl Phys Lett 2010; 96:243701. doi: 10.1063/1.3449575.

19. Chang JW, Kang SU, Shin YS, Kim KI, Seo SJ, Yang SS, Lee JS, Moon E, Baek SJ, Lee K, Kim CH. Nonthermal atmospheric pressure plasma induces apoptosis in oral cavity squamous cell carcinoma: involvement of DNA-damage-triggering sub-G1 arrest via the ATM/p53 pathway. Arch Biochem Biophys 2014;545:133-140. doi: 10.1016/j.abb.2014.01.022.

20. Lee JH, Om JY, Kim YH, Kim KM, Choi EH, Kim KN. Selective Killing effects of cold atmospheric pressure plasma with no induced dysfunction of epidermal growth factor receptor in oral squamous cell carcinoma. PLoS One 2015;10:e0129931. doi: 10.1371/journal.pone.0150279.

21. Ishaq M, Kumar S, Varinli H, Han ZJ, Rider AE, Evans MD, Murphy AB, Ostrikov K. Atmospheric gas plasma-induced ROS production activates TNF-ASK1 pathway for the induction of melanoma cancer cell apoptosis. Mol Biol Cell 2014;25:1523-1531. doi: 10.1091/mbc.E13-10-0590.

22. Utsumi F, Kajiyama H, Nakamura K, Tanaka H, Mizuno M, Ishikawa K, Kondo H, Kano H, Hori M, Kikkawa F. Effect of indirect nonequilibrium atmospheric pressure plasma on anti-proliferative activity against chronic chemoresistant ovarian cancer cells in vitro and in vivo. PLoS One 2013;8:e81576. doi: 10.1371/journal.pone.0081576.

23. Nkembo AT, Salako O, Poku RA, Amissah F, Ntantie E, Flores-Rozas H, Lamango NS. Disruption of actin filaments and suppression of pancreatic cancer cell viability and migration following treatment with polyisoprenylated cysteinyl amides. Am J Cancer Res 2016;6:2532-2546.

24. Thomas E, Gopalakrishnan V, Hegde M, Kumar S, Karki SS, Raghavan SC, Choudhary B. A novel resveratrol based tubulin inhibitor induces mitotic arrest and activates apoptosis in cancer cells. Sci Rep 2016;6:34653. doi: 10.1038/srep34653.

25. Yim KS, Kim SG, Park BS, Go DS, Kim CS, Kim DK. Resveratrol induces the apoptosis associated with activation of caspases in HTB-41 human salivary gland epidermoid carcinoma cells. Oral Biol Res 2016;40:16-23.

26. Leprêtre $\mathrm{C}$, Tchakarska G, Blibech $\mathrm{H}$, Lebon $\mathrm{C}$, Torriglia A. Apoptosis-inducing factor (AIF) and leukocyte elastase inhibitor/L-DNase II (LEI/LDNaseII), can interact to conduct caspase independent cell death. Apoptosis 2013;18:1048-1059. doi: 10.1007/s10495-013-0862-2.

27. Kim SJ, Chung TH. Cold atmospheric plasma jet-generated RONS and their selective effects on normal and carcinoma cells. Sci Rep 2016;3:20332. doi: 10.1038/srep20332. 